\title{
UJI pH DAN KARAKTER FISIS PADA AIR MANISAN BUAH SALAK SIDEMPUAN (Salacca sumatrana)
}

\author{
Sumiati, Aji Suroso, Shabri Putra Wirman, Sri Fitria Retnowaty \\ Program Studi Fisika, Fakultas MIPA dan Kesehatan \\ Universitas Muhammadiyah Riau
}

\begin{abstract}
ABSTRAK
Salak merupakan salah satu jenis tanaman dengan buah yang dapat dimakan dan merupakan tanaman asli Indonesia. Salah satu jenis makanan yang dapat dibuat dengan salak adalah manisan. Akan tetapi manisan salak yang tersedia di zaman yang serba modern ini, dalam proses pembuatannya sering ditambahkan dengan asam benzoat. Maka dari itu perlu diteliti mengenai kualitas dari manisan salak tersebut. Penlitian yang dilakukan yaitu pada karakteristik fisis dan $\mathrm{pH}$ dari air manisan buah salak, dengan membandingkan berbagai jenis manisan salak yang divariasikan pada penambahan jumlah asam benzoat. Parameter yang digunakan pada uji fisis yaitu berupa Viskositas, Total Padatan Terlarut (TPT), massa jenis, Konduktivitas, Resistivitas, Oxidation Reduction Potential (ORP), Salinitas, dan uji rasa. Dan hasil dari penelitian yang diperoleh menunjukkan jika variasi sampel $1 \mathrm{~kg}$ salak, 0,5 kg gula, 1 gram asam benzoat dan 1,5 liter air, memiliki nili pH fisis (konduktivitas dan ORP) terbaik. Dan untuk nilai viskositas dan resistivitas terbaik terdapat pada sampel dengan variasi sampel tanpa penambahan asam benozoat yaitu $1 \mathrm{~kg}$ salak, $0,5 \mathrm{~kg}$ gula, 1 gram asam benzoat dan 1,5 liter air.
\end{abstract}

Kata Kunci: Salak, Manisan Salak, Asam benzoat, uji pH, Uji fisis

\section{PENDAHULUAN}

Salak merupakan salah satu jenis tanaman dengan buah yang dapat dimakan dan merupakan tanaman asli Indonesia. Salak tersebar di berbagai daerah tropis Indonesia dan memiliki banyak manfaat serta mempunyai beragam jenis, seperti Salak Pondoh, Salak Bali, Salak Sidempuan, Salak Lokal dan lain sebagainya. Kandungan gizi yang terkandung dalam buah salak cukup tinggi diantaranya protein, karbohidrat, kadar abu, kalsium, posfor dan zat besi [1,2].

Manfaat yang dihasilkan dari buah salak untuk tubuh manusia yaitu dapat mengobati diare, kesehatan kulit, kuku dan mata. Pada buah salak terdapat kulit ari yang sangat tipis yang berkhasiat untuk memperlancar Buang Air Besar (BAB). Selain memiliki kelebihan salak juga memiliki kelemahan, yaitu mudah rusak dan busuk serta memiliki rasa kelat pada salak tertentu [3].

Salak dapat dimakan serta disajikan sebagai buah segar dan juga dapat diolah menjadi berbagai jenis makanan. Salah satu jenis makanan yang dapat dibuat dengan salak adalah manisan.
Manisan salak adalah salah satu cara agar salak tetap bisa dimanfaatkan dan untuk menghindari menumpuknya salak yang busuk, serta dapat menghilangkan rasa kelat pada buah salak tersebut. Manisan merupakan bentuk olahan makanan yang banyak disukai oleh masyarakat dan memiliki rasa khas dengan buah yang akan diolahnya. Akan tetapi manisan salak yang tersedia di zaman yang serba modern ini, dalam proses pembuatannya sering ditambahkan dengan asam benzoat. Tujuan dari penambahan asam benzoat selain agar lebih tahan lama dan lebih manis, faktor ekonomis juga menjadi salah satu alasan penambahan asam benzoat tersebut. Jika manisan salak yang mengandung asam benzoat tersebut dikonsumsi dalam jumlah tertentu, maka akan menimbulkan efek yang berbahaya bagi tubuh [4].

Penelitian tentang manisan telah banyak dilakukan dengan berbagai macam buah diantaranya yaitu oleh Wahyu Ratna Dewi pada pengolahan jambu biji bangkok dan mempelajari sifat fisis dan $\mathrm{pH}$ yang disimpan dalam lemari pendingin, pengaruh cara pengolahan manisan 
nanas terhadap tingkat kesukaan konsumen oleh Aniswatul Khamidah, pengaruh konsentrasi gula dan lama

Penyimpanan terhadap mutu manisan cabai basah oleh Sanggam Dera Rosa Tampubolon, kemudian keragaman jenis kapang pada manisan buah salak (Salacca edulis Reinw) oleh Rhatih Damayanti, serta sifat antioksidasi, sifat kimia dan sifat fisis manisan basah dari kunir putih oleh Dwiyati Pujimulyani $[5,6,7,8,9]$.

Pada penelitian ini diteliti tentang karakteristik fisis dan $\mathrm{pH}$ dari manisan buah salak, dengan membandingkan berbagai jenis manisan salak yang divariasikan pada penambahan jumlah asam benzoat (pengawet makanan). Parameter yang digunakan pada uji fisis yaitu berupa Viskositas, Total Padatan Terlarut (TPT), massa jenis, Konduktivitas, Resistivitas, Oxidation Reduction Potential (ORP), Salinitas, dan Organoleptik berupa rasa serta uji $\mathrm{pH}$.

\section{METODOLOGI PENELITIAN}

\section{Alat}

Alat yang digunakan dalam penelitian ini yaitu seperangkat peralatan dapur (panci besar, sendok, pisau dapur, baskom dan sebagainya), 1 set $\mathrm{pH}$ meter tipe SX751 dengan Portable pH/ORP/Conductivity/DO Meter, 1 set tabung viskometer Ostwald, stopwatch, neraca digital dan Gelas ukur.

\section{Bahan}

Bahan yang akan digunakan diantaranya buah salak, gula pasir, asam benzoat, garam, buah cabe dan air.

\section{Prosedur Kerja}

Cara pembuatan dari air manisan salak yaitu dengan mengupas $1 \mathrm{~kg}$ buah salak dan mengambil dagingnya, selanjutnya dicuci bersih dan ditiriskan. Setelah itu merebus air sebanyak 1,5 liter, sampai mendidih, kemudian memasukkan buah salak ke dalamnya dengan mengaduk sampai buah salak masak setengah matang. Angkat buah salak dan ditiriskan. Air bekas rebusan digunakan untuk memasak lagi dengan menambahkan $0,5 \mathrm{~kg}$ gula, 25 gr garam dan 25 gr buah cabe. Masak air yang dicampur dengan gula, garam dan buah cabe tersebut hingga air tersisa setengah dari awal merebusnya. Langkah terakhir yaitu memasukkan buah salak ke dalam air rebusan tersebut sambil mengadukaduk, kemudian didiamkan selama satu malam agar meresap.

Untuk variasi air manisan salak tersebut dalam proses membuat air manisan salak selanjutnya divariasikan dalam bahan pengawet, yaitu asam benzoat. Berikut variasi dari penambahan asam benzoat yang dicampurkan dalam air manisan salak.

a. Sampel A yaitu air manisan salak murni (tanpa campuran).

b. Sampel B yaitu air manisan salak dengan penambahan asam benzoat 0,2 gram.

c. Sampel C yaitu air manisan salak dengan penambahan asam benzoat 0,4 gram.

d. Sampel D yaitu air manisan salak dengan penambahan asam benzoat 0,6 gram.

e. Sampel E yaitu air manisan salak dengan penambahan asam benzoat 0,8 gram.

f. Sampel F yaitu air manisan salak dengan penambahan asam benzoat 1 gram.

Setiap variasi sampel tersebut dibuat sebanyak 6 botol sebanyak $50 \mathrm{ml}$ untuk setiap botolnya. Tujuan dari hal tersebut yaitu untuk keperluan pengujian selama 6 hari. Alur dalam penelitian ini dapat dilihat pada Gambar 1.

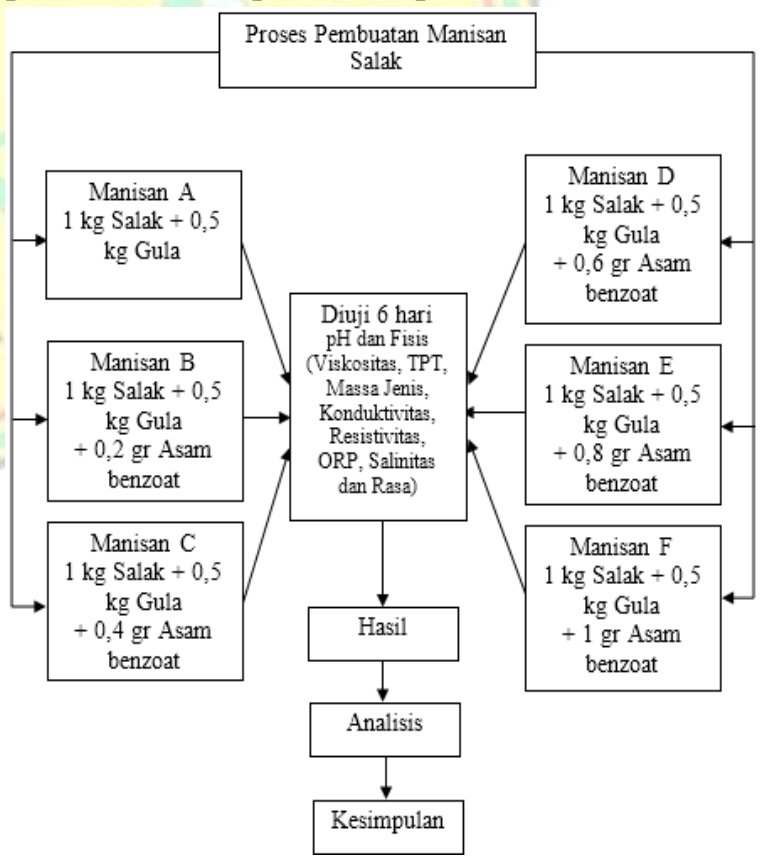

Gambar.1. Diagram Alur Uji Air manisan salak 


\section{Uji pH}

Pada uji $\mathrm{pH}$ sampel air akan diukur dengan menggunakan $\mathrm{pH}$ meter. Cara penggunaanya yaitu dengan memasukkan alat ini ke dalam air manisan salak yang ingin diketahui nilai pHnya. Dan alat yang dimasukkan adalah pendeteksi nilai $\mathrm{pH}$ yang telah dihubungkan dengan layar yang berfungsi untuk menampilkan nilai $\mathrm{pH}$. Pengukuran nilai $\mathrm{pH}$ dilakukan sebanyak 3 kali.

\section{Uji Viskositas}

Uji Viskositas dilakukan menggunakan viskometer Ostwald dengan cara memasukan air ke dalam alat viscometer Ostwald. Cara menggunakan viskometer Ostwald yaitu, air manisan salak dipakai sebagai pembanding, pertama air dimasukkan melalui tabung A kemudian dihisap agar masuk ke tabung B tepat sampai batas a kemudian dilepaskan dan siapkan stopwatch sebagai pengukur waktu. Jika waktu yang diperlukan air untuk bergerak dari permukaan a sampai $b$ adalah $t 1$, maka percobaan diganti dengan zat cairan lain yaitu aquadest.

Jika diperlukan $\mathrm{t} 2$ dengan menggunakan rumus Poiseville karena V, L dan R sama maka didapat persamaan (2.1) [13].

$$
\frac{\eta_{1}}{\eta_{2}}=\frac{T_{1}}{T_{2}} \frac{\rho_{1}}{\rho_{2}}
$$

Dengan $\gamma \_1$ adalah massa jenis air 1 dan $\gamma \_2$ merupakan massa jenis manisan yang dicari. Dan untuk mendapatkan nilai viskositas maka nilai $\mathrm{t}$ (waktu) yang diuji dalam penelitian ini.

Pada viskometer Ostwald yang diukur adalah waktu yang dibutuhkan oleh air manisan untuk mengalir melalui pipa kapiler dengan gaya yang disebabkan oleh manisan itu sendiri, jadi waktu yang dibutuhkan oleh manisan untuk melalui batas "a" dan "b" dapat diukur menggunakan stop watch [11].

\section{Uji Total Disolve Solid (TDS)}

Uji Total Padatan Terlarut (TPT) atau Total Disolve Solid (TDS), menggunakan alat yang sama dengan $\mathrm{pH}$ meter. Perbedaanya yaitu dengan mengganti alat pendeteksi pada alat tersebut.Alat tersebut terdapat di dalam satu paket dengan $\mathrm{pH}$ meter. Untuk membaca nilainya dilihat pada display dengan menekan fungsinya ke dalam fungsi TDS. Dalam pengujian tersebut dilakukan pengulangan sebanyak 3 kali.

\section{Uji Massa Jenis}

Untuk pengujian massa jenis caranya yaitu dengan memasukkan air manisan kedalam gelas ukur sebanyak $25 \mathrm{ml}$, dimana sebelumnya gelas ukur telah ditimbang terlebih dahulu. Kemudian ditimbang untuk menentukan massa air manisan salak. Selanjutnya untuk menghitung nilai massa jenis air manisan salak, maka digunakan persamaan 2.1 .

$$
\rho=\frac{m}{v}
$$

\section{Uji Konduktivitas}

Uji konduktivitas dilakukan dengan menggunakan alat yang sama dengan TDS meter. Untuk membaca nilainya dilihat pada display dengan menekan fungsinya ke dalam fungsi konduktivitas. Dalam pengujian tersebut dilakukan pengulangan sebanyak 3 kali.

Sama halnya dengan uji konduktivitas dan TDS uji resistivitas juga dilakukan dengan menggunakan alat yang sama. Dan untuk membaca nilainya dilihat pada display dengan menekan fungsinya ke dalam fungsi resistivitas. Dalam pengujian tersebut dilakukan pengulangan sebanyak 3 kali.

\section{Uji Oxidation Reduction Potential (ORP)}

Uji ORP juga digunakan alat yang sama, hanya saja alat pendeteksi diganti dengan pendeteksi ORP. Kemudian. Untuk membaca nilainya dilihat pada display dengan menekan fungsinya ke dalam fungsi ORP. Dalam pengujian tersebut dilakukan pengulangan sebanyak 3 kali.

\section{Uji Salinitas}

Sama halnya dengan uji konduktivitas, TDS dan resistivitas uji salinitas juga dilakukan dengan menggunakan alat yang sama. Untuk membaca nilainya hanya dengan melihat pada display dengan menekan fungsinya ke dalam fungsi salinitas. Dalam pengujian tersebut dilakukan pengulangan sebanyak 3 kali. 


\section{Uji Rasa (Organoleptik)}

Uji rasa dilakukan dengan cara memberikan sampel air manisan salak kepada 10 orang dewasa berjenis kelamin laki-laki dan perempuan dengan usia antara 25 hingga 40 tahun. Para panelis tersebut diminta untuk mencoba rasa air manisan salak tersebut. Dan pilihan dari rasa tersebut yaitu dengan memberi nilai 1 untuk "suka" dan 2 untuk "tidak suka". Tabel 1 menunjukkan nama panelis berdasarkan jenis kelamin dan usianya.

Tabel. 1. Tabel daftar nama panelis

\begin{tabular}{|l|c|c|c|}
\hline \multirow{2}{*}{ NAMA } & \multirow{2}{*}{ UMUR } & \multicolumn{2}{c|}{ JENIS KELAMIN } \\
\cline { 3 - 4 } & & LAKI-LAKI & PEREMPUAN \\
\hline Bu Karni & 39 & & $\sqrt{ }$ \\
\hline Bu Sunarti & 38 & & $\sqrt{ }$ \\
\hline Bu Justinar & 39 & & $\sqrt{ }$ \\
\hline Bu Noperlinda & 37 & & $\sqrt{ }$ \\
\hline Bu Siti Fadiyah & 39 & & \\
\hline Pak Sayuti & 39 & $\sqrt{ }$ & \\
\hline Pak Ali & 37 & $\sqrt{ }$ & \\
\hline Pak Giatmo & 38 & $\sqrt{ }$ & \\
\hline Pak Sudarto & 38 & $\sqrt{ }$ & \\
\hline Pak Asep & 39 & $\sqrt{ }$ & \\
\hline
\end{tabular}

\section{HASIL DAN PEMBAHASAN}

Setelah melakukan penelitian terhadap air manisan salak, maka telah diperoleh beberapa data dari $\mathrm{pH}$, viskositas, Total Padatan Terlarut (TPT), massa jenis, konduktivitas, Oxidation Reduction Potential (ORP), resistivitas, salinitas dan rasa.

\section{pH}

Gambar 2 menunjukkan jika nilai $\mathrm{pH}$ pada manisan A, B, C, D, E dan F. Gambar tersebut dapat dilihat menunjukkan jika semua sampel manisan cenderung menurun stabil dari hari pertama hingga hari kelima. Kemudian pada hari keenam nilai $\mathrm{pH}$ untuk semua manisan naik kembali. Hal tersebut menunjukkan jika nilai $\mathrm{pH}$ semakin menurun berdasarkan lamanya penyimpanan. Menurunnya $\mathrm{pH}$ dapat disebabkan karena perubahan suhu pada saat pengukuran nilai $\mathrm{pH}$ pada manisan. Selain itu, $\mathrm{pH}$ suatu manisan akan terus menurun (semakin asam) berdasarkan lamanya waktu penyimpanan. Jadi semakin lama air manisan salak disimpan maka nilai $\mathrm{pH}$ manisan tersebut akan semakin asam [11].

Nilai $\mathrm{pH}$ terendah dapat dilihat pada air manisan salak murni tanpa penambahan asam benzoat yaitu pada manisan A. Sedangkan manisan dengan penambahan asam benzoat memiliki nilai $\mathrm{pH}$ yang relatif besar. Semakin banyak penambahan asam benzoat maka nilai $\mathrm{pH}$ akan semakin besar. Seperti yang dapat dilihat pada manisan $\mathrm{E}$ dan $\mathrm{F}$ yang memiliki nilai $\mathrm{pH}$ stabil hingga hari keempat

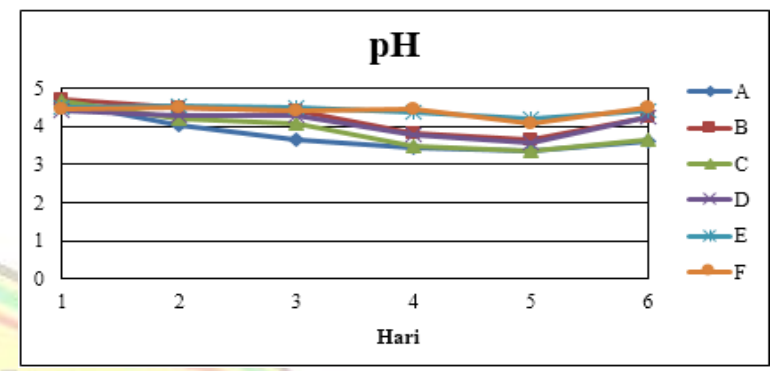

Gambar. 2. Hubungan Nilai pH Air Manisan Salak dengan Lamanya Penyimpanan

Jika dibandingkan dengan nilai $\mathrm{pH}$ pada sampel A dengan sampel lainnya, maka sampel A memiliki nilai $\mathrm{pH}$ paling rendah diantara sampel lainnya. Hal tersebut dikarenakan sampel A merupakan sampel tanpa penambahan asam benzoat. Selain itu faktor suhu pada saat pengkuran juga menjadi salah satu penyebab rendahnya nilai $\mathrm{pH}$ pada sampel A. Dimana semakin tinggi suhu pada saat pengukuran, maka nilai $\mathrm{pH}$ juga semakin tinggi (Lampiran 1).

Dari nilai $\mathrm{pH}$ pada semua sampel tersebut menunjukkan, bahwa pencampuran asam benzoat mampu mempengaruhi besar dan kecilnya nilai pH manisan pada air manisan salak. Sehingga dengan nilai yang $\mathrm{pH}$ yang besar maka manisan tidak mudah asam dan basi. Dan mampu membuat manisan lebih tahan lama [11, 21].

Dari hasil penelitian nilai $\mathrm{pH}$ air manisan salak semakin menurun jika disimpan semakin lama. Dengan demikian hal ini menunjukan bahwa air manisan salak akan semakin asam. Selain perubahan nilai $\mathrm{pH}$ yang juga dipengaruhi oleh perbedaan penambahan asam benzoat ke dalam larutan. Perubahan $\mathrm{pH}$ karena lama penyimpanan menyebabkan kerusakan air manisan salak yang ditandai dengan rasa air manisan salak yang semakin asam dan warnanya menjadi lebih kecoklatan [11].

Penambahan asam benzoat mengakibatkan nilai $\mathrm{pH}$ air manisan salak meningkat, hal ini dapat disebabkan oleh asam asam benzoat yang 
dapat meningkatkan keefektifan dalam menghambat mikroorganisme. perkembangbiakan perkembangbiakan mikroorganisme, maka makin rendah pula aktivitas mikroorganisme yang dapat mengubah gula menjadi asam dan alkohol [11, 21].

\section{Viskositas}

Pada Gambar 3 dapat dilihat jika manisan A dan $C$ naik jauh di hari kedua dari hari pertama, dan untuk B, D, E dan F sedikit menurun dihari kedua. Pada hari berikutnya yaitu hari ketiga manisan $\mathrm{A}, \mathrm{D}, \mathrm{E}$ dan $\mathrm{F}$ cenderung menurun kemudian naik di hari keempat. Selanjutnya manisan A dan Enaik di hari kelima dan menurun di hari keenam. Sedangkan pada manisan D dan F menurun di hari kelima dan naik di hari keenam. Untuk manisan $\mathrm{B}$ dan $\mathrm{C}$ nilai $\mathrm{pH}$ cenderung stabil hingga hari ke empat. Akan tetapi manisan B naik dihari kelima dan menurun kembali di hari keenam. Perubahan nilai viskositas pada sampel A, B, C, D, E dan F dapat disebabkan karena adanya perbedaan suhu pada saat pengukuran nilai viskositas.

Dari tersebut dapat dilihat jika kekentalan air manisan salak cenderung meningkat berdasarkan lamanya penyimpanan. Kekentalan cairan dipengaruhi oleh suhu, bila suhu cairan meningkat maka kekentalan menurun dan sebaliknya bila suhu cairan turun maka kekentalan cairan meningkat (Lampiran 1 no 2). Sedangkan penambahan asam benzoate tidak memberikan pengaruh terhadap nilai viksositas manisan salak. Hal tersebut dapat dilihat pada manisan $\mathrm{F}$ yang cenderung stabil hingga hari keempat dan memiliki nilai viskositas yang lebih rendah dibandingkan sampel lainnya $[11,21]$.

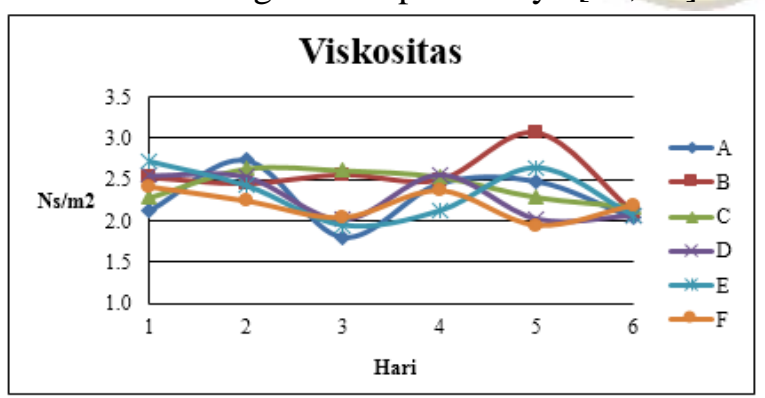

Gambar. 3. Hubungan Nilai Viskositas Air Manisan Salak Dengan Lamanya Penyimpanan.

\section{Total Disolve Solid (TDS)}

Dari Gambar 4 manisan A, B, D, E dan F di hari pertama memiliki nilai Total Padatan Terlarut (TPT) yang berbeda. Nilai TPT pada gambar tersebut menunjukkan jika pada semua sampel manisan memiliki kesamaan pada nilai tersebut, yaitu cenderung menurun jauh di hari kedua. Kemudian nilai TPT pada semua manisan cenderung sama (stabil) untuk minggu berikutnya hingga minggu terakhir. Akan tetapi, nilai naik jauh di hari ketiga dan cenderung stabil hingga hari kelima kemudian turun pada hari keenam (terakhir). Menurunnya nilai TPT di hari kedua dari hari pertama dapat disebabkan karena pada hari pertama air manisan salak masih baru. Dimana padatan adalah bahan yang masih tetap tinggal sebagai sisa selama penguapan dan pemanasan pada suhu $103^{\circ} \mathrm{C}-105^{\circ} \mathrm{C}$ [22]

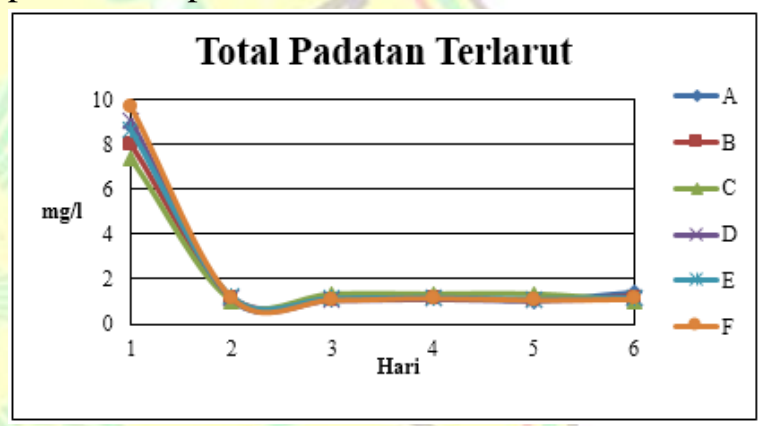

Gambar. 4. Hubungan Nilai TPT Air Manisan Salak Dengan Lamanya Penyimpanan

Berdasarkan gambar tersebut, nilai total padatan terlarut semakin menurun selama penyimpanan, hal ini dapat disebabkan kandungan gula pereduksi menurun, karena terjadi penguraian gula pereduksi menjadi alkohol, asam dan $\mathrm{CO}_{2}$. Total padatan terlarut air manisan salak menurun dengan semakin besar konsentrasi asam asam benzoat, hal ini disebabkan oleh pengaruh gula yang terdapat pada manisan berikatan dengan kation $\mathrm{Na}+$ yang mempengaruhi struktur gel yang terbentuk sehingga ion yang bebas menjadi terikat [22].

Dari nilai TPT yang telah didapatkan maka penambahan asam benzoat tidak mempengaruhi besar kecilnya nilai TPT pada air manisan salak. Hal tersebut dapat dilihat berdasarkan lamanya penyimpanan dari manisan tersebut. Dimana nilai TPT cenderung stabil, yaitu tidak mengalami perubahan yang cukup jauh pada setiap 
pengukuran. Dengan nilai TPT tersebut maka air manisan salak tidak mengandung unsur (padatan) atau bahan kimia yang tinggi di dalamnya [14].

\section{Massa Jenis}

Gambar 5 yang menunjukkan jika nilai massa jenis dengan lamanya penyimpanan. Berdasarkan gambar tersebut terlihat jika massa jenis pada manisan sampel F memiliki nilai yang cukup jauh berbeda dengan sampel manisan lainnya. Sampel F merupakan sampel dengan penambahan asam benzoat paling banyak. Nilai massa jenis sampel F cenderung berubah-ubah pada setiap pengukuran nilai massa jenis.

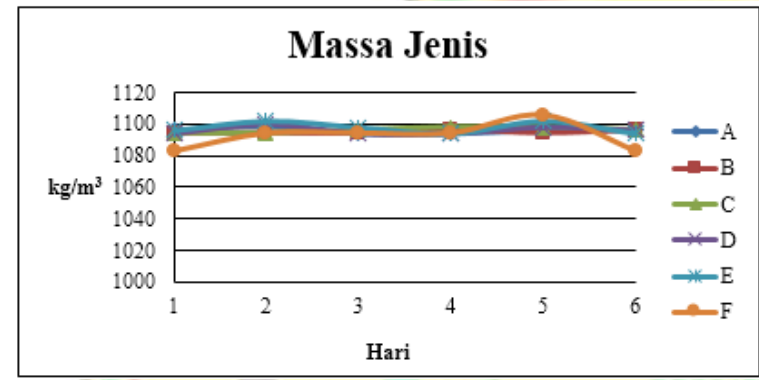

Gambar. 5. Hubungan Nilai Massa Jenis Air Manisan Salak Dengan Lamanya Penyimpanan

Sehingga dengan hasil tersebut maka dengan semakin banyak jumlah penambahan asam benzoat. Nilai massa jenis dari manisan salak cenderung berubah-ubah berdasarkan lamanya penyimpanan.

Selain itu nilai massa jenis dapat dipengaruhi oleh temperatur dan tekanan dari cairan itu sendiri. Dimana massa jenis akan berpengaruh pada temperatur yang cukup tinggi. Sehingga pada perubahan temperatur yang rendah tidak mempengaruhi nilai massa jenis. Dan tekanan dari cairan itu sendiri dapat disebabkan karena adanya zat di dalam cairan tersebut. Akan tetapi hasil yang didapatkan nilai massa jenis cukup berubah signifikan pada air manisan dengan jumlah penambahan asam benzoat terbanyak. Sehingga asam benzoat mempengaruhi nilai massa jenis pada air manisan salak [15, 21].

\section{Konduktivitas}

Nilai konduktivitas yang ditunjukkan Gambar 6 untuk semua manisan naik di hari kedua dari hari petama. Kemudian cenderung stabil dihari berikutnya hingga hari terakhir pengukuran. Nilai konduktivitas tersebut naik dan turun disetiap pengukuran. Akan tetapi naik dan turun nilai tersebut tidaklah terlalu jauh dari hari sebelumnya. Sehingga nilai konduktivitas tersebut dapat dikatakan stabil pada setiap pengukuran. Nilai konduktivitas yang didapatkan pada manisan salak cukup tinggi yaitu berada pada rentang 1050-1990 $\mathrm{Ohm}^{-1}$.

Perubahan nilai konduktivitas manisan salak dapat dipengaruhi oleh perubahan suhu pada saat pengukuran data. Dimana hubungan suhu dan konduktivitas adalah berbanding terbalik, jika suhu semakin besar maka konduktivitas akan semakin kecil. Dengan dihasilkanya nilai konduktivitas yang cukup tinggi, maka manisan salak memiliki kandungan elektrolit yang tinggi [16].

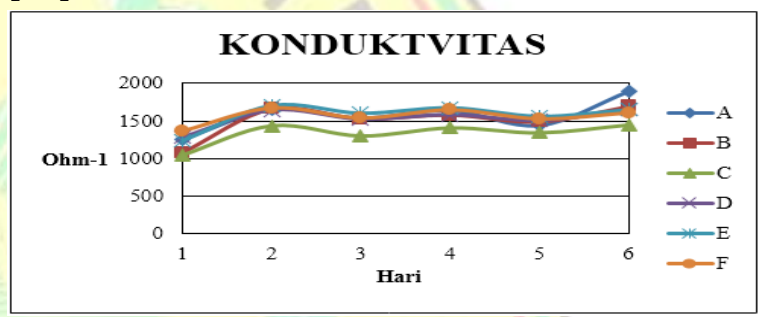

Gambar. 6. Hubungan Konduktivitas Air Manisan Salak Dengan Lamanya Penyimpanan

Dalam suatu larutan apabila konsentrasi ion $\mathrm{H}+$ meningkat berarti ion $\mathrm{OH}-n y a$ menurun, berarti bahwa ion $\mathrm{H}+$ mudah bergerak dalam larutan tersebut, sehingga larutan bersifat asam dan konduktivitas listriknya meningkat. Penambahan asam asam benzoat dapat meningkatkan konduktivitas listrik bahan, karena asam asam benzoat dapat terurai menjadi ion asam $(\mathrm{Na}+)$ bebas. Semakin besar konsentrasi ion $\mathrm{Na}+$ menyebabkan mobilitas ion semakin tinggi, sehingga konduktivitas listrik meningkat [11, 23].

\section{Resistivitas}

Resisitivitas merupakan kemampuan suatu cairan dalam memperlambat (menghambat) aliran listrik. Nilai resistivitas yang ditunjukkan pada Gambar 7 untuk semua variasi manisan menurun dihari kedua dari hari pertama. Setelah itu nilai resistivitas cenderung stabil dihari 
berikutnya hingga hari terakhir pengukuran nilai resistivitas. Jika waktu penyimpanan yang lama menyebabkan nilai konduktivitas meningkat, maka berbeda dengan nilai resistivitas. Nilai resistivitas cenderung menurun berdasarkan lamanya penyimpanan.

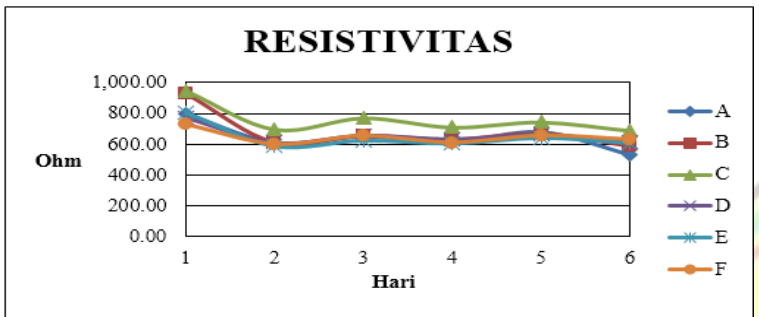

Gambar. 7. Hubungan Resistivitas Air Manisan Salak Dengan Lamanya Penyimpanan

Larutan yang semakin asam menyebabkan nilai resistivitas menurun. Konsentrasi ion $\mathrm{H}+$ yang meningkat menyebabkan ion $\mathrm{OH}-$ menurun dan tidak mudah bergerak dalam larutan tersebut, sehingga larutan bersifat asam dan resistivitas menurun [16].

Nilai resistivitas berkurang akibat adanya ion-ion yang bersifat asam, basa, maupun garam yang terlarut dalam air manisan salak. Ion-ion yang terlarut dalam air dapat meningkat secara dramatis bila ada zat yang terdapat dalam manisan tersebut. Zat yang terdapat dalam air manisan salak merupakan zat buatan. Dan dalam air manisan salak zat tersebut adalah asam asam benzoat. Nilai resistivitas yang naik atau turun secara drastis cenderung dipengaruhi oleh zat buatan seperti asam asam benzoat [16].

\section{Oxidation Reduction Potential (ORP)}

Gambar 8 menunjukkan nilai ORP untuk semua manisan. Nilai ORP untuk manisan B, C, $\mathrm{D}, \mathrm{E}$ dan $\mathrm{F}$ menurun sangat jauh di hari kedua dari hari pertama. Kemudian nilai tersebut stabil hingga hari terakhir pengukuran. Pada hari pertama manisan A menunjukkan hasil yang berbeda dari manisan lainnya.

Dari hari pertama nilai ORP manisan A menunjukkan nilai yang rendah dan cenderung stabil hingga hari terakhir pengukuran. Dengan perbedaan nilai manisan A dengan lainnya, maka penambahan asam benzoat mampu mempengaruhi nilai ORP pada air manisan salak. Hal tersebut dapat dilihat dari sampel manisan dengan penambahan asam benzoat yang memiliki nilai ORP lebih tinggi.

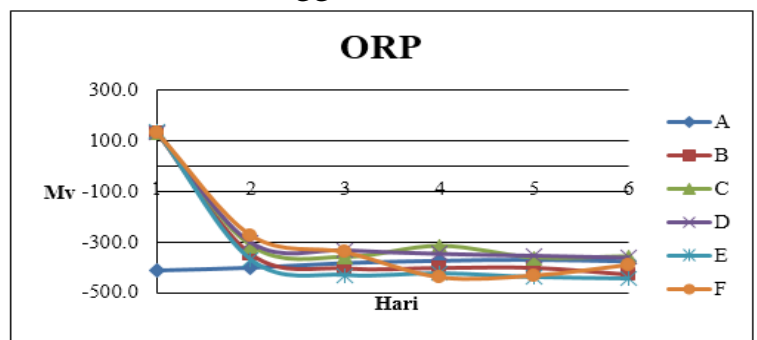

Gambar. 8. Hubungan ORP Air Manisan Salak Dengan Lamanya Penyimpanan

Penambahan asam benzoat mempengaruhi nilai ORP lebih tinggi. Sedangkan tanpa penambahan asam benzoat nilai rendah dari hari pertama hingga keenam (terakhir). Akan tetapi, semakin tinggi nilai ORP maka semakin mudah reaksi oksidasi terjadi dan semakin banyak membran sel pada air manisan salak yang rusak dan mati. Sehingga air manisan salak menjadi lebih cepat basi (rusak) [18].

\section{Salinitas}

Nilai salinitas yang ditunjukkan pada Gambar 9 untuk semua manisan cenderung naik turun pada setiap pengukuran. Pada hari kedua nilai salinitas mengalami kenaikan. Akan tetapi kenaikan nilai tersebut tidak terlalu jauh dari hari pertama. Dengan perubahan tersebut maka nilai salinitas dapat dikatakan stabil pada setiap pengukuran. Hal tersebut karena naik dan turunnya nilai salinitas tidak terlau besar dari hari sebelumnya. Perubahan nilai salinitas dapat dipengaruhi oleh nilai $\mathrm{pH}$ dari air manisan salak itu sendiri. Dimana jika nilai $\mathrm{pH}$ air manisan salak tersebut naik juga naik turun pada setiap pengambilannya. Dan air manisan salak yang mengandung senyawa asam kuat dan basa kuat akan memiliki sifat netral dengan rasa yang asin [16].

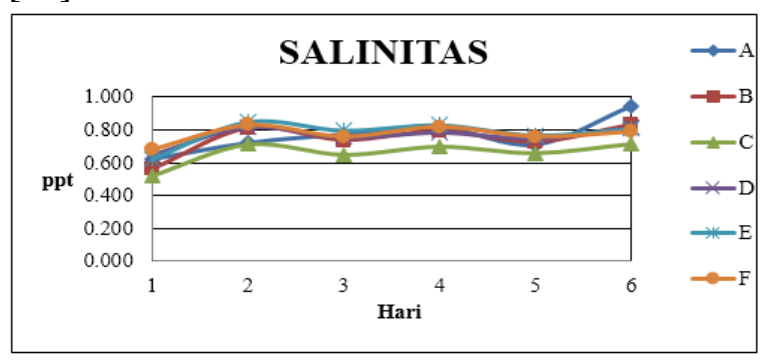

Gambar. 9. Hubungan Salinitas Air Manisan Salak Dengan Lamanya Penyimpanan 


\section{Rasa}

Data hasil dari uji rasa dapat dilihat pada Gambar 55 - 60. Hasil dari uji rasa berupa angka yang menunjukkan tingkat kesukaan panelis dan angka tersebut yaitu 1 untuk rasa suka dan 2 untuk tidak suka.

Pada gambar tersebut menunjukkan jika semua manisan disukai hingga hari kedua. Sedangkan pada Gambar 10 menunjukkan jika dihari ketiga hingga hari terakhir penyimpanan, rasa pada manisan A tidak disukai. Kemudian untuk sampel B (Gambar 11) dan C (Gambar 12), rasa masih disukai hingga hari ketiga dan tidak disukai pada hari keempat hingga hari terakhir.

Gambar 13 menunjukkan hasil uji rasa pada sampel D. Gambar tersebut menunjukkan jika manisan masih disukai hingga hari keempat dan tidak disukai pada hari kelima hingga keenam.

Sedangkan untuk sampel E (Gambar 14) dan F (Gambar 15), kedua sampel manisan tersebut disukai oleh semua panelis hingga haru kelima dan tidak disukai hingga hari terakhir penyimpanan.

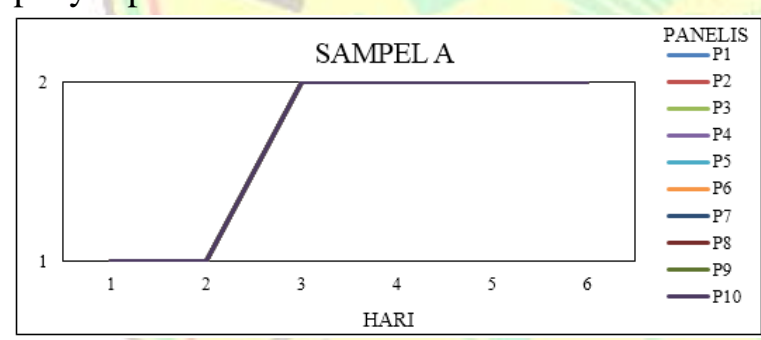

Gambar. 10. Hubungan Uji Rasa Sampel A

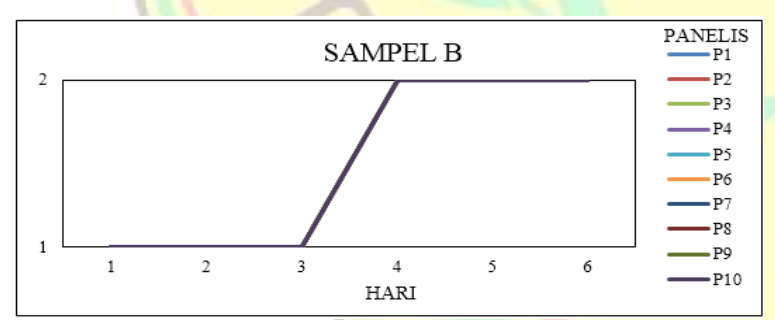

Gambar. 11. Hubungan Uji Rasa Sampel B

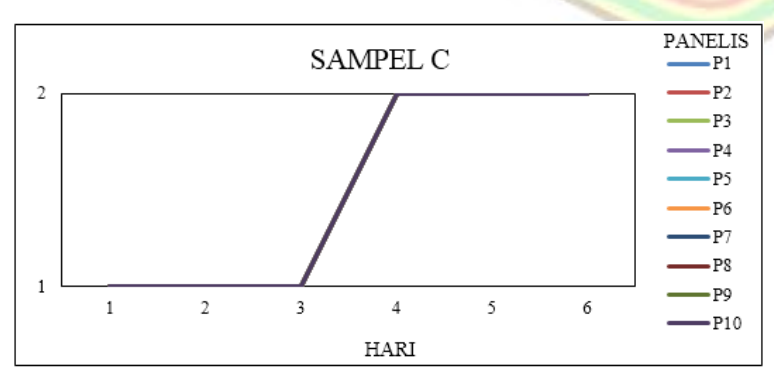

Gambar. 12. Hubungan Uji Rasa Sampel C

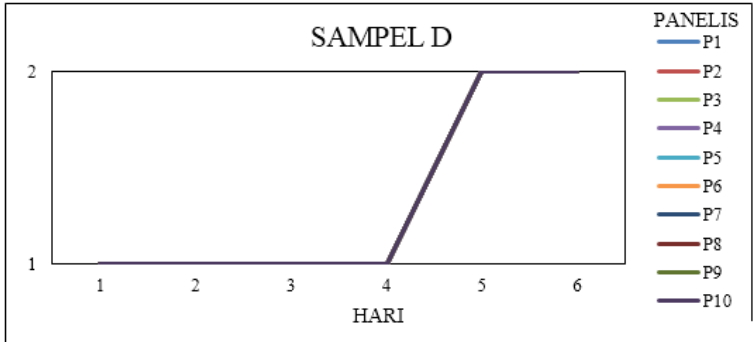

Gambar. 13. Hubungan Uji Rasa Sampel D

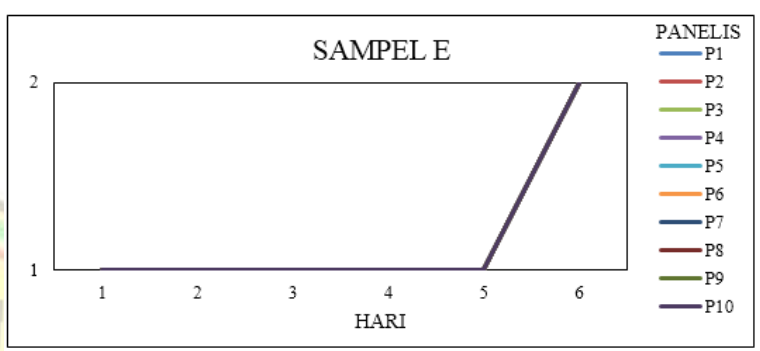

Gambar. 14. Hubungan Uji Rasa Sampel E

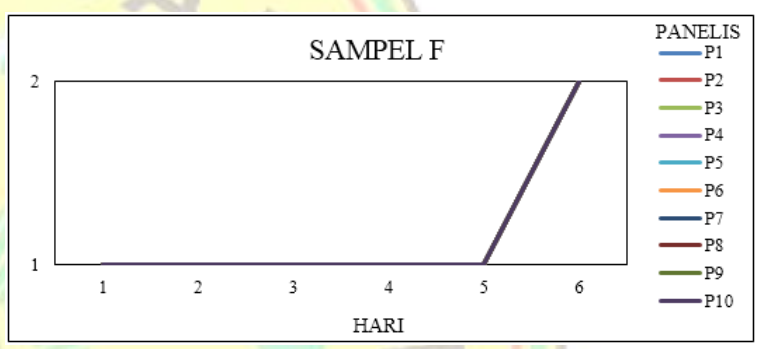

Gambar. 15. Hubungan Uji Rasa Sampel F

Hasil dari uji organoleptik tersebut menandakan jika semakin banyak asam benzoat yang ditambahkan, maka akan semakin lama dan banyak disukai air manisan salak tersebut. Sehingga asam benzoat mampu memberikan pengaruh terhadap rasa dari air manisan salak [20].

\section{KESIMPULAN}

Berdasarkan analisa data serta hasil di atas maka dapat diambil beberapa kesimpulan diantaranya:

1. Nilai $\mathrm{pH}$ terbaik terdapat pada sampel $\mathrm{F}$ yaitu dengan variasi $1 \mathrm{~kg}$ salak, $0,5 \mathrm{~kg}$ gula, 1 gram asam benzoat dan 1,5 liter air dengan nilai 4,5.

2. Pada uji fisis nilai konduktivitas dan ORP terbaik terdapat pada sampel $\mathrm{F}$ yaitu dengan variasi $1 \mathrm{~kg}$ salak, $0,5 \mathrm{~kg}$ gula, 1 gram asam benzoat dan 1,5 liter air, dengan nilai masingmasing 1609 Ohm dan 389 Mv.

3. Kemudian untuk nilai viskositas dan resistivitas nilai terbaik terdapat pada sampel 
A, yaitu tanpa penambahan asam benzoat yaitu dengan variasi $1 \mathrm{~kg}$ salak, $0,5 \mathrm{~kg}$ gula, dan 1,5 liter air dengan nilai masing-masing yaitu $2,12 \mathrm{Ns} / \mathrm{m}^{2}$ dan $796 \mathrm{Ohm}^{-1}$

\section{DAFTAR PUSTAKA}

Direktorat Gizi. 1994. Komposisi Salak Daging Buah Salak, Nenas dan Apel Dalam Setiap I00 gram. Departemen Kesehatan Republik Indonesia 1994.

Maya, Dede. 2006. Analisis Efisiensi Penggunaan Faktor-Faktor Produksi Dan Pendapatan Usahatani Salak Bongkok. Bogor. Fakultas Pertanian Institut Pertanian Bogor.

Dhamayanti R, Suranto, Ratna S. 2002. Keragaman Jenis Kapang pada Manisan Buah Salak (Salacca edulis Reinw.), Jurusan Biologi, UNS Surakarta.

Kurniadi Muhamad. 2005. Aplikasi Teknik Hot Filling Dalam Pengalengan Salak. Yogyakarta. Implementasi Hasil Penelitian dan Pengembangan Pertanian Untuk Kesejahteraan Masyarakat.

Ratna, W. Dewi. 2005. Pengolahan Manisan Jambu Bangkok Dan Mempelajari Beberapa Sifat Fisik dan pHnya Yang Disimpan Pada Lemari Pendingin, Penelitian S-1 Fisika, Institut Pertanian Bogor, Bogor.

Khamidah, Aniswatul dan Eliartati. 2009. Pengaruh Cara Pengolahan Manisan Nanas Terhadap Tingkat Kesukaan Konsumen. Riau. Balai Pengkajian Teknologi Pertanian Jawa Timur dan Balai Pengkajian Teknologi Pertanian Riau.

Tampubolon Sanggam, D.R. 2006. Pengaruh

Konsentrasi Gula Dan Lama Penyimpanan Terhadap Mutu Manisan Cabai Basah. Medan. Jurnal Pertanian Bidang Ilmu Pertanian Volume 4, Nomor 1. Universitas Sumatra Utara.

Pujimulyani, D. Dan Wazyka, A. 2005. Sifat Antioksida dan Sifat Fisik Manisan Basah Dari Kunir Putih, Agritech,Vol.29 No.3.Agustus 2009. Universitas Mercu Buana. Yogyakarta.
HA Idrus. 1996. Membuat aneka makanan terlaris untuk home industry. Yogyakarta. Aneka.

Kantor Deputi Menegristek Bidang Pendayagunaan dan Pemasyarakatan Ilmu Pengetahuan dan Teknologi Gedung II BPP Teknologi Lantai 6, Jl. M.H. Thamrin 8 Jakarta 10340.

Mariance, Rince. 2006. Karakteristik Fisik dan pH Sari Wortel. Bogor. Institut Pertanian Bogor. Skripsi.

Budianto, Anwar. 2008. Metode Penentuan Koefisien Viskositas Zat Cair Dengan Menggunakan Regresi Linier Hukum Stokes. Seminar Nasional SDM Teknologi Muklir Yogyakarta, 25-26 Agustus 2008. ISSN 1978-0176.

Fitriyanto, dkk. 2013. Kajian Viskositas Dan Berat Jenis Susu Kambing Peranakan Etawa (Pe) Pada Awal, Puncak Dan Akhir Laktasi. Purwokerto. Fakultas Peternakan, Universitas Jendral Soedirman Purwokerto.

Quality Assurance Departement. PT Ades Waters Indonesia Tbk.

Sears dan Zemansky. 1999. Fisika Universitas Edisi 10 Jilid 1. Jakarta. Erlangga.

Kurnian Alfa, dkk. Identifikasi Kualitas Air Berdasarkan Nilai Resistivitas Air. Yogyakarta. Studi Kasus: Kali Gajahwong Hazmi Ariadi, dkk. 2012. Penghilangan Mikroorganisme dalam Air Minum dengan Dielectric Barrier Discharge. Padang.Jurusan Teknik Kimia, Fakultas Teknologi Industri, Universitas Bung Hatta.

Rahma Siti. 2009. Pencitraan Dua Dimensi Data Resistivity Dan Induced Polarization Untuk Mendelineasi Deposit Emas Sistem Epithermal Di Daerah "X". Jakarta. Fakultas Matematka Dan Ilmu Pengetahuan Alam, Univerrsitas Indonesia. Gustian Irfan, Totok E. Suharto. 2005. Studi Penurunan Salinitas Air Dengan Menggunakan Zeolit Alam Yang Berasal Dari Bengkulu. Bengkulu. Jurusan Kimia, Fakultas Matematika dan Ilmu Pengetahuan Alam, Universitas Bengkulu, 
Jurnal Gradien Vol.1 No. 1 Januari 2005:38-42.

Zuhra Cut. F. 2006. Flavor (Cita Rasa). Medan. Karya Ilmiah Universitas Sumatra Utara. Kristianingrum Susila, M.Si. 2006. Asam benzoat Makanan Yang Aman Bagi Kesehatan. Yogyakarta. Jurusan Pendidikan Kimia Fakultas Matematika dan Ilmu Pengetahuan Alam. Universitas Negeri Yogyakarta.

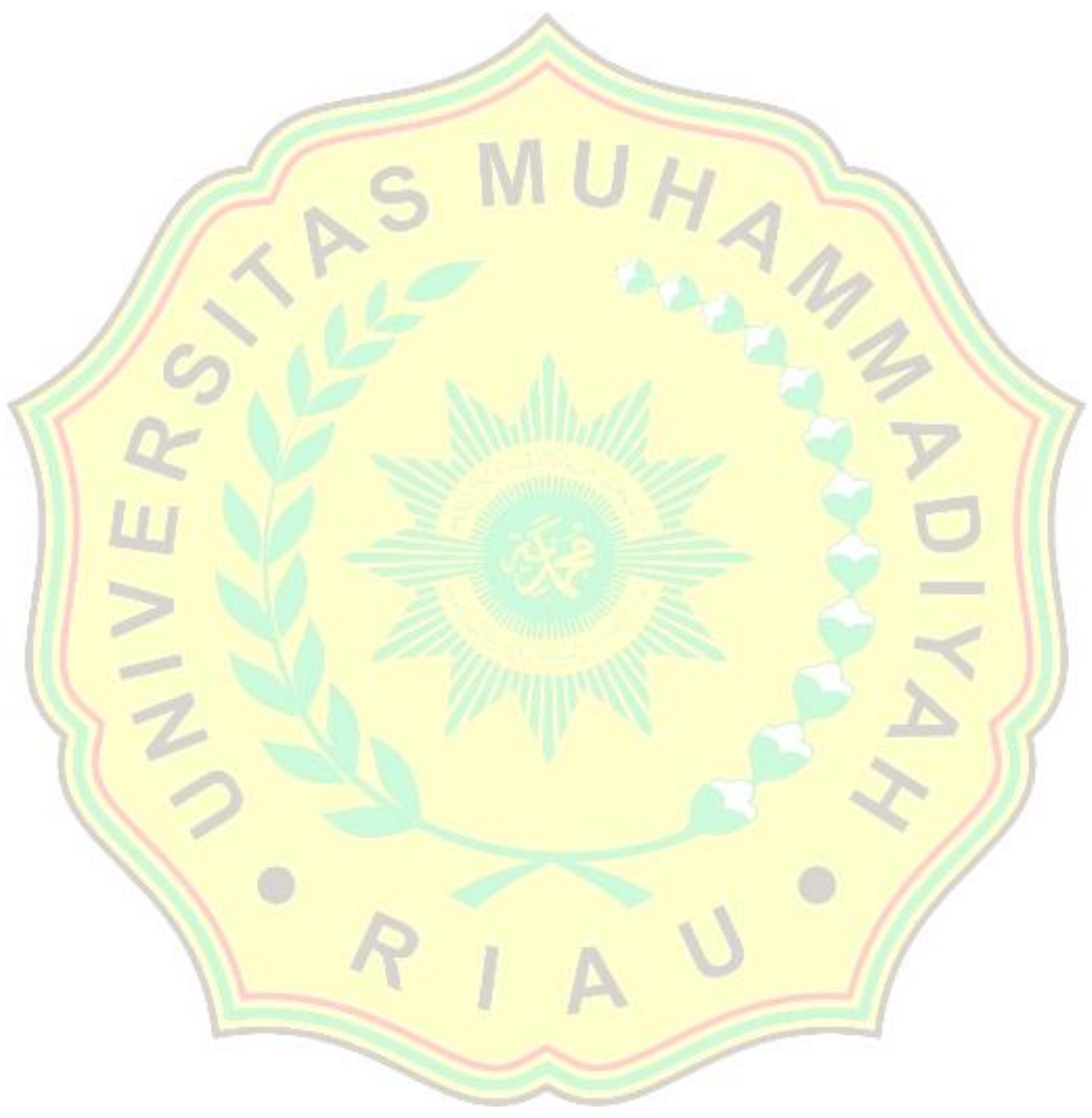

